\title{
A tarefa evangelizadora no Novo Mundo e a gente de cor nas Minas Gerais*
}

\author{
La evangelización en el Nuevo Mundo \\ $y$ las personas de color en Minas Gerais \\ The task of evangelization in the New World \\ and people of color in Minas Gerais
}

Mônica Ribeiro Oliveira**

\begin{abstract}
Resumo: Esse artigo tem como objetivo acompanhar o comportamento de negros e mestiços livres, ou mais genericamente, a gente de cor no século XVIII, no sertão das Minas, através da instância religiosa. Para essa finalidade nos servimos das visitações eclesiásticas por meio das quais a Igreja buscava se afirmar e acompanhar de perto a vivência católica nas localidades, reprimindo o que considerava atos ilícitos e zelando pelos bons costumes. A interpretação dos documentos produzidos por essas visitações nos permite a compreensão dos costumes cotidianos da população, o sentido do matrimônio legítimo, a coexistência de práticas de uniões informais e a percepção do lugar ocupado pelas forras e índias nas suas relações com seus senhores. Através da recuperação dessas experiências acessamos as tensões e os conflitos que informavam as inter-relações entre os grupos ali estabelecidos, bem como o exercício de solidariedades horizontais que solidificavam alianças e recriavam identidades.
\end{abstract}

Palavras chaves: sociedade colonial; igreja no século XVIII; libertos

Resumen: Este artículo tiene como objetivo estudiar el comportamiento de los negros y mestizos libres, o más en general, la gente de color en el siglo XVIII, en el interior de Minas Gerais, a través de instancia religiosa. Para tanto utilizamos las visitaciones

\footnotetext{
* O presente artigo resulta de uma investigação de Pós-doutorado (Bolsa Capes) desenvolvida na Universidad Pablo de Olavide de Sevilla. Conta com financiamento do Conselho Nacional de Desenvolvimento Científico e Tecnológico (CNPq) e da Fundação de Amparo à Pesquisa do Estado de Minas Gerais (FAPEMIG).

** Professora Titular da Universidade Federal de Juiz de Fora. Possui doutorado em História Social pela Universidade Federal Fluminense. É pesquisadora do CNPq e desenvolve estudos sobre o comportamento de negros e mestiços livres, ou mais genericamente, a gente de cor no século XVIII, na América Portuguesa.<monicaufff@gmail.com>.

Full professor at the Universidade Federal de Juiz de Fora, having a doctoral degree in Social History from the Universidade Federal Fluminense. She is a CNPq researcher with a project on the behavior of free blacks and mestizos, or, generally speaking, the people of color in the 18th century in Portuguese America. <monicaufjf@gmail.com>.
} 
eclesiásticas por las cuales la iglesia trató de hacer valer su posición y vigilar de cerca a la vivencia católica de los pueblos, haciendo la represión de lo que ella consideraba actos ilícitos y garantizar las buenas costumbres. La interpretación de los documentos producidos por estas visitaciones nos permite entender las costumbres cotidianas de la población, el sentido del matrimonio legítimo, la coexistencia de uniones informales y la percepción del lugar ocupado por las libertas, las indígenas en sus relaciones con sus amos. Por la recuperación de estas experiencias hemos tenido acceso a las tensiones y conflictos que informaron las interrelaciones entre los grupos establecidos allí y, por otro lado, el ejercicio de la solidaridad horizontal que solidificó alianzas y ha recreado las identidades.

Palabras clave: sociedad colonial; iglesia en el siglo XVIII; libertos

Abstract: This article aims to analyze the behavior of free blacks and mestizos, or more generally, the people of color in the $18^{\text {th }}$ century, in the backlands of Minas Gerais, in the religious context. To this purpose, the ecclesiastical visitations, by which the Church sought to assert and closely monitor Catholic life in its locales, working to suppress what it considered illicit acts and to ensure proper modes of behavior, are taken as source. Interpretation of the documents produced by these visitations offers an understanding of the everyday life and the customs of the population, the meaning of legitimate marriage, the coexistence of practices of informal unions, and the perception of the place occupied by freed slave and indigenous women in their relations with their husbands. By recovering these experiences, we had access to the tensions and conflicts that informed the interrelationships between the groups established there, as well as to the practices of horizontal solidarity that consolidated alliances and recreated identities.

Keywords: colonial society; Church in the $18^{\text {th }}$ century Catholic Church; free persons

Em 1730, na localidade da Borda do Campo na Capitania de Minas Gerais, Inácia Dias, escrava de José Dias de Carvalho, foi denunciada por concubinato com seu senhor e também com outro indivíduo chamado Antônio Machado da Cunha' ${ }^{1}$. Uma meticulosa pesquisa nas devassas promovidas pelas visitações do Bispado de Mariana demonstrou que Inácia esteve envolvida em variadas denúncias por concubinato, na maioria das vezes referida como escrava e com uma única menção a Isabel Carijó, sua mãe. Em seu primeiro depoimento confessava ter "cometido culpas com o dito Antonio Machado e com o mesmo dito senhor andava até aqui concubinada, mas não por sua vontade, antes tinha um grande horror a culpa que cometia pela circunstância de ter também andado concubinada o dito seu senhor com Isabel Carijó, mãe dela cúmplice, o que o seu dito era tomar o estado de casada, mas que seu

${ }^{1}$ Termo de delito e penalidade do denunciado - Borda do Campo - Arquivo Eclesiástico da Cúria de Mariana - 10/01/1730. 
senhor não lhe queria consentir." Diante da exposição de tal infortúnio o visitador ordenou que deveriam ser dados a ela meios espirituais e temporais para ser apartada da situação que a constrangia e foi condenada ao pagamento de três mil réis, pagos pelo denunciado (FIGUEIREDO, 1997) ${ }^{2}$. O visitador, imbuído dos valores propugnados pela doutrina jesuítica, reprimiu o comportamento senhorial, obrigando-o a nunca mais retornar à casa aonde pecavam e a pagar uma multa. Os senhores deveriam dar bons exemplos à sua própria família e aos escravos, proibindo-os de cultivar os "prazeres do ócio".

Essas duas devassas datam de 10 e 12 de janeiro de 1730, no entanto, quatro dias depois o crime ganhou outras conotações e nova devassa foi aberta. Desta vez, a condição de denunciado coube ao próprio senhor de Inácia Dias, José Dias de Carvalho ${ }^{3}$. O delito da penalidade baseava-se no indício de incesto, que passou despercebido na devassa anterior, ou melhor, parece-nos que separaram o julgamento por distintos réus. Agora a vez seria do próprio senhor de Inácia, a responder pelo delito de amancebamento com sua mãe e presunção de incesto. Como de costume, o denunciado aceitou a culpa, informando que um dia antes já teria emitido carta de liberdade não só para a dita escrava, como a dois filhos dela e a cúmplice foi recolhida à casa de uma "pessoa honesta". O denunciado alegou "ser um homem com mais de sessenta anos que vive com pobreza e nessas distancias e deserto requeria a ele o dito reverendo o sentenciasse camerariamente". O visitador achou por bem que o cúmplice havia feito a sua parte e as "referidas demonstrações e aos seus anos, pobreza e distância do país em que vivia e obediência ...", obrigou-lhe o pagamento de uma multa comutando-lhe as penas corporais. Pelos gravíssimos delitos foram aplicadas penitências medicinais e caso faltasse ao prometido poderia ser excomungado. No documento consta a carta de alforria passada a Inácia e aos seus dois filhos.

A referência à distância de seu país e ao deserto que vivia, o sertão da Mantiqueira, foi utilizada como atenuante da culpa do denunciado. Sabiam aqueles indivíduos que aquela era uma terra sem lei e utilizavam dessa situação para se auto beneficiarem. Sabia-se também que a menção à pobreza e idade avançada seriam dois outros atenuantes de uma condenação mais rigorosa. Em nenhum momento no auto das denúncias

${ }^{2} \mathrm{O}$ valor desta condenação costumeira era irrisório. Referia-se ao preço de 15 bananas ou a uma medida de aguardente. $\mathrm{O}$ efeito teria que ser mais moral do que financeiro ao denunciado.

${ }^{3}$ Termo de delito e penalidade do denunciado - Borda do Campo - Arquivo Eclesiástico da Cúria de Mariana - 10/01/1730. 
ou mesmo na carta de alforria emitida foi levantada a origem indígena de Inácia ou que fosse possivelmente, uma administrada. A menção a ela foi assim feita na carta "senhor e possuidor de uma parda de nome Inácia Dias”.

Três anos depois ela foi novamente denunciada por concubinato com Pedro Jaques Lemes ${ }^{4}$. Na devassa, a menção a Inácia foi novamente como escrava de José Dias de Carvalho. O denunciado aceitou a admoestação, prometeu não procurá-la mais, não ir à sua casa e pagou a multa. Inácia confessou a culpa, mas não foi feita nenhuma referência a pena pecuniária e penitencial cobrada através de rezas. Seria tão miserável a condição da pobre mulher que não lhe couberam nem as costumeiras penas?

No entanto, pelo desenrolar dos acontecimentos, estamos tentados a pensar que não era bem essa a justificativa. No mesmo dia, outra devassa envolveu seu nome e, como denunciado ${ }^{5}$, novamente seu senhor, José Dias de Carvalho, pelo mesmo crime ${ }^{6}$. Os termos da denúncia estavam mais claros. José Dias teria que se apartar da ilícita comunicação que tinha com a sua escrava e lhe foi ordenado que "em termo de dois dias a lance fora de casa sob pena de excomunhão”. Ou seja, Inácia ainda era considerada juridicamente uma escrava, apesar da carta de alforria ter sido documentada e assinada abaixo de sua segunda denúncia três anos antes e ainda compartilhava o teto com José, mas não sabemos em que condições. Não há referências a penas para ambos denunciados. Realizada a denúncia coube ao visitador uma simples averiguação e compromisso de suspensão da "ilícita comunicação" que tinham. Por que Inácia não fez valer a carta de emancipação passada três anos antes? Neste momento Inácia teria uma relação consensual com seu senhor? Além disto, mantinha por sua própria vontade, relações com outros homens livres recebendo-os em sua casa? No contexto de uma sociedade escravista, herdeira de uma cultura política de Antigo Regime fortemente hierarquizada, a aplicação da justiça dava-se de acordo com cada lugar socialmente ocupado. (LEVI, 2009) Condenação, mas comiseração, perdão, comutação de penas - atitudes que couberam ao pobre colono

\footnotetext{
${ }^{4}$ Termo de delito e penalidade do denunciado - Borda do Campo - Arquivo Eclesiástico da Cúria de Mariana - 08/09/1733.

${ }^{5} \mathrm{M}$. Leônia C. Resende elaborou uma lista com o nome dos principais administradores de índios para a região e nela encontramos os nomes Alberto Dias e José Dias. Por mais que existam homônimos nas fontes do período, acreditamos que, pelo cruzamento das informações, se trate realmente dos envolvidos nessas devassas (RESENDE, 2003).

${ }^{6}$ Termo de delito e penalidade do denunciado - Borda do Campo - Arquivo Eclesiástico da Cúria de Mariana - 08/09/1733.
} 
português. E a Inácia, somente a condenação, como se a decisão sobre seu destino dependesse de sua vontade individual.

Uma nova denúncia envolvendo Inácia Dias foi registrada dois dias depois. Novamente denunciada por concubinato com Domingos Luís da Silva, só que desta vez, foi referida como bastarda índia de cor amarela ${ }^{7}$. Apenas nessa última devassa sua real origem étnica foi revelada. Talvez ela fosse uma escrava de ganho e usasse da prostituição para seu sustento, o que não era improvável, e a permanência ao lado de seu antigo dono poderia trazer-lhe mais benefícios do que o exercício de sua autonomia, engrossando o grupo das demais pretas, mulatas e pardas forras da localidade. Os indícios do comportamento de Inácia através das diferentes autuações pelos visitadores nos levam a importantes questionamentos. Sua permanência ao lado de seu antigo senhor, mesmo com uma carta de alforria passada publicamente e anexada ao processo, nos sugere que antes de uma condição de submissão a uma relação de poder, sua permanência poderia ser uma consequência de uma escolha ${ }^{8}$. Mas é preciso levar em consideração quais os constrangimentos e incentivos canalizavam as escolhas dos indivíduos (BARTH, 1981, p. 34). Realçar somente os significados positivos como se estivessem livremente gerenciando seus destinos em contraposição a uma posição de vítima da violência senhorial que as reduziria à condição de objeto do poder, é passar de um extremo a outro. O que queremos problematizar é que os indivíduos, inseridos em um determinado momento histórico e submetidos a pressões de ordem emocionais, econômicas e do próprio meio social e cultural a que pertenciam, não possuíam o completo controle racional de suas alternativas. Para nós o comportamento de Inácia não representava o exercício de autonomia, antes, porém significava a ausência de universos alternativos que a constrangiam e a estimulavam a aceitar a sua condição.

Estas passagens referem-se às devassas ocorridas na região da Mantiqueira por razão da visita pastoral do clérigo Manoel Freire Batalha, comissário do Santo Ofício em janeiro de 1730. O Tribunal do Santo Ofício não conseguiu se estabelecer na América Portuguesa,

\footnotetext{
${ }^{7}$ Termo de delito e penalidade do denunciado - Borda do Campo - Arquivo Eclesiástico da Cúria de Mariana -11/09/1733.

${ }^{8}$ Essa possibilidade coaduna com muitas referências historiográficas que tendem a valorizar o grau de autonomia destas mulheres e de como utilizavam das brechas do sistema de exploração para se auto beneficiarem. Ressalta-se que essas pesquisas se basearam nas áreas urbanas. Para isso consultar: PAIVA, E.F, 2001 e FURTADO, 1996.
} 
porém, os tentáculos da Inquisição de Lisboa se estenderam no ultramar português por meio de diversas estratégias que iam desde a formação de um corpo de "Familiares do Santo Ofício"9 até as visitações eclesiásticas, por meio de seus agentes e comissários. Os comissários constituíam um mecanismo fundamental para a engrenagem da ação inquisitorial na Colônia e as visitações pastorais visavam, antes de tudo, tornar o clero mais presente nas distantes localidades da cristandade $^{10}$. Luciano Figueiredo ressalta o papel das visitações na defesa da igreja enquanto um local sagrado de exercício do culto e para isso as visitações deveriam combater crenças e práticas populares e reprimir a conduta dos padres (FIGUEIREDO, 1997; SOUZA, 1986; 1994; FIGUEIREDO; SOUSA, 1987; TORRES-LONDOÑO, 1999). Inspiradas no Concílio de Trento e regulamentadas pelas Constituições Primeiras do Arcebispado da Bahia, as visitações buscavam afirmar e acompanhar de perto a vivência católica nas localidades, reprimindo o que considerava atos ilícitos e zelando pelos bons costumes. Na prática, usava de intimidação para tentar aplacar aquilo que era considerado uma vivência profana e transgressão moral. Manuel Freire Batalha, o primeiro visitador no arraial da Borda do Campo, habilitou-se ao cargo de agente da inquisição em 1730 e teve uma profunda ação inquisitorial na capitania, principalmente em relação aos cristãos novos. Ordenava prisões e enviava réus a serem ouvidos no Santo Ofício em Lisboa, no entanto, sua pastoral nos sertões da Mantiqueira atenderia a finalidades muito mais de ordenamento social e censura ao comportamento dos clérigos do que a repressão às heresias.

A presença da Igreja na localidade da Borda do Campo no sertão da Mantiqueira em 1730 possuiu dois importantes significados ${ }^{11}$. Revelou, primeiramente, a disposição da Igreja em se fazer presente nas em áreas distantes, antecipando-se à Coroa, no processo de incorporação das novas regiões conquistadas. Por outro lado, expôs quão frágil era esse controle do Estado português que após 30 anos dos

\footnotetext{
9 Os familiares eram os oficiais leigos do Santo Ofício, escolhidos entre as pessoas com reputação e de bom cabedal, residentes tanto em Portugal quanto na América Portuguesa. Entre o os candidatos que atendiam aos pré-requisitos necessários para pleitear o cargo de familiar da inquisição incluíam-se "pessoas de bom procedimento e de confiança e capacidade reconhecida", que tivessem "fazenda de que possam viver abastadamente". Além disso, eles deveriam ser "naturais do reino, cristãos-velhos, de limpo sangue, sem raça de mouro, judeu ou gente novamente convertida" Consultar: KÜHN, 2010, p. 177-195.

${ }^{10}$ Para Paiva havia uma relação de complementariedade entre as visitações e a inquisição. Caberia à primeira a observância e punição dos crime da moral e bons costumes e à segunda a punição aos atos de heresia (PAIVA, 1989, p. 89-90).

${ }^{11}$ Sobre as visitações na Borda do Campo, ver também RESENDE, 2003 e CRUZ, 2009.
} 
descobertos auríferos, ainda não havia conseguido se impor no espaço das minas ${ }^{12}$.

Dez anos antes uma ordem régia proibiu a ocupação na região, à exceção das sesmarias oficialmente concedidas. A esta se sucederam outras proibições, em 1733, 1750, até o bando de 1755 que confirmou o Distrito da Mantiqueira como área proibida. Tendo em vista a criação de várias localidades nas áreas proibidas, conclui-se que nenhuma ordem da Coroa foi cumprida até meados do XVIII e que não havia meios para fazê-la cumprir. Antes do Estado caberia à igreja, com seu projeto moralizador, a tarefa de interiorização representando uma outra face do poder, a tentar submeter todos os grupos ali presentes, desde a carijó prostituída, negras forras, colonos portugueses empobrecidos e os ricos tenentes coronéis das corporações. A comunidade que reunia aqueles indivíduos constituía um grupo em que todos se conheciam e se vigiavam, em torno dos quais se estendia uma terra incógnita, os sertões, habitado por personagens reais ou lendários, que povoavam o imaginário social. A sede da Freguesia da Borda do Campo, somada a outros lugarejos ainda mais diminutos, constituía o espaço habitado e ocupado segundo determinadas leis, mas leis estas regidas mais pelo costume do que pela ação de uma justiça reguladora e formal.

A chegada dos visitadores tinha que ser precedida pela leitura pública de um edital, que deveria ser afixado na porta da paróquia, constando os crimes a serem ser denunciados. Celebrava-se uma missa e depois desta seguiam-se vinte e quatro horas para denúncia dos crimes. Dadas as condições rudimentares do povoado não havia nem uma igreja em condições de receber a ilustre visita e, supomos que esta deva ter sido realizada na casa de algum grande proprietário (FIGUEIREDO, 1987). A população incitada a denunciar, prevendo castigos e danações ao não o fazer, produzia uma série de delações. Muitas delas podiam ser movidas simplesmente pelo desejo de vingança ou apenas pela prática costumeira da censura e controle da vida pessoal. Após as denúncias, nesta ou em próximas visitações, o denunciado deveria se apresentar, admitir a culpa, receber oficialmente a admoestação e proceder ao pagamento das multas. Nestas sociedades os limites entre o público e o privado eram tênues (ARIÈS, 2009).

\footnotetext{
${ }^{12}$ Assim consideramos por mais que se justifique por meio da existência do padroado, que igreja e Estado agiam juntos e que a primeira sempre agia a serviço do segundo, os visitadores propugnavam ali uma tarefa evangelizadora de acordo com seus próprios princípios doutrinais. Para maiores discussões acerca do padroado, consultar: BOSCHI, 1989, p. 65.
} 
O escândalo público do que era realizado "portas adentro" era apropriado por todos. Acrescenta-se a esse aspecto cultural, próprio das sociedades de Antigo Regime, um importante fator singular da sociedade local: mais do que em outras épocas da colonização aquela era uma sociedade caracterizada pela pluralidade, formada por indivíduos com diferentes orientações valorativas, como os paulistas, portugueses, indígenas e africanos, em sua maioria recém-chegada na localidade. Questionamos se aquela sociedade já teria criado laços de solidariedades coletivas e comunitárias que pudessem consolidar estas inter-relações? Talvez estivesse ainda por criá-los, o que abria espaço para coexistência de valores e expectativas muito heterogêneos, como também para o florescimento de redes de clientela.

As devassas refletem, principalmente, o universo dos pobres, certamente os mais atingidos pelas delações. Através delas temos acesso ao universo das práticas cotidianas da população, o sentido do matrimônio legítimo e a coexistência de práticas de amancebamento ou simplesmente o concubinato, o lugar ocupado pelas forras, índias, as relações entre os senhores e suas escravas aos quais se julgavam no direito de ampliar seu direito de propriedade à posse sexual. R.Vainfas destaca como a deturpada visão europeia de caos moral e desregramento sexual da colônia impregnou não só as narrativas dos primeiros a discorrer sobre elas, os viajantes, mas várias gerações posteriores de trabalhos (VAINFAS, 1989). Para essa tradição, seríamos o resultado de uma população mestiça herdeira da licenciosidade das relações sexuais entre brancos, índios e negros (FREIRE,1989). Vainfas questiona, até que ponto a colônia seria tão desregrada. Para ele devemos entender a persistência dessas práticas no contexto do escravismo. As dificuldades burocráticas para financiamento do matrimônio eclesiástico, somadas à instabilidade social e mobilidade espacial das camadas mais pobres explicariam os elevados índices de concubinato.

Voltando a trajetória de Inácia, ela nos possibilita perceber o quanto a licenciosidade das relações dos senhores com suas escravas fazia parte da cotidianidade e, neste caso, fazia parte de uma conduta familiar. Dois dias antes da denúncia de José, seu irmão, Alberto Dias de Carvalho foi igualmente denunciado por concubinato e defloramento de sua escrava parda Domingas Dias. O agravante da situação era que esta parda que havia sido dada como sobrinha de Alberto, filha de José Dias de Carvalho. A parda Domingas seria, então, filha de uma relação extraconjugal de José com uma escrava, possivelmente uma índia administrada. Era comum a apropriação indiscriminada de índias ao 
plantel de cativos, que passavam a ser designadas, simplesmente, por pardas $^{13}$. A Carta Régia de 1696 foi o instrumento legal que incumbiam os proprietários de cuidar da doutrinação cristã à população indígena, surgindo daí a condição de administradores de índios. Tal situação só mudaria com o Alvará de 1758 que decretava a liberdade plena aos índios, o que não impediu, certamente, que muitos continuassem na condição de cativos. (CAPRI, 1916, p. 257) A incorporação dos indígenas à escravaria impediu uma visão clara das origens dos grupos sociais envolvidos não só nas devassas, mas em todas as fontes do período.

Esse caso da mestiça Domingas Dias, nomeada como escrava, mas sobrinha de seu senhor, nos remete ao fenômeno da reescravização, ao qual ficavam submetidas as gerações subsequentes das índias administradas. Alberto Dias de Carvalho foi denunciado por adultério, estupro e incesto e teve sua situação piorada pela denúncia paralela de que consentia que seu escravo Pedro fizesse curas "com presunção de superstição pelo que tudo foi logo asperissimamente repreendido pelo visitador", além de culpa anterior de concubinato em outra freguesia. Por possuir mais de sessenta anos e ser casado suas penas foram aliviadas e comutadas, cabendo o pagamento de uma multa mais alta e, por conta do estupro comprovado e confesso, foi obrigado a concederlhe a alforria e um dote, para seu futuro casamento. Essa exigência por si só demonstra a condição social distinta de Domingas em relação às inúmeras outras denúncias de trato ilícito de senhores para com suas escravas, o que mais reforça nosso argumento de sua origem mestiça e certamente de tez mais clara. Muitas africanas eram defloradas por seus senhores, brancos e casados, sem nenhuma compensação às vítimas. A própria exigência de casamento após denúncia por concubinato só era feita às mulheres livres e sem vínculos com o cativeiro. A justiça religiosa aplicada a cada grupo distintamente favoreceu Domingas Dias e esta estava mais apta a beneficiar-se de alguma compensação. Sua qualidade $^{14}$ e sua origem a colocavam num outro lugar na hierarquia social, ou seja, no grupo dos não brancos, composto por negros, pardos

\footnotetext{
${ }^{13}$ Maria Leônia Chaves de Resende elaborou uma lista com o nome dos principais administradores de índios e nela encontramos os nomes Alberto Dias e José Dias. Por mais que existam homônimos nas fontes do período, acreditamos que, pelo cruzamento das informações, se trate realmente dos envolvidos nessas devassas (RESENDE, 2003).

${ }^{14}$ Destacamos o termo "qualidade" como aquele utilizado nas fontes de época para a definição dos indivíduos. Ela diz respeito ao lugar social, como também a forma como os homens se apresentavam e eram reconhecidos socialmente (FRAGOSO, 2000).
} 
e outros mestiços, ela se distinguia em uma mobilidade horizontal (LEVI, 2009).

Pela fala da acusada Domingas, ela não tinha escolha "aceitava a admoestação da emenda e que por não mais poder tinha com seu senhor caído nesse pecado, mas que estava disposta a largar quanto da sua parte estivesse e que para este feito não tinha dúvida a tomar o estado de casada e foi condenada em quatro oitavas (...) e com algumas penitências espirituais”. A fala de Domingas reforça a sua ausência de alternativas, o seu constrangimento àquela situação. Quanto à atuação do bispo, a este interessava a punição dos pecados à luz da Reforma Tridentina, sem questionar a natureza da escravidão.

$\mathrm{Na}$ denúncia feita contra Alberto o Visitador frei Batalha asseverava (...) pondo-se ao perigo de perder a sua salvação por haver deflorado e mostrado outrossim a pouco que cuidava de ser bom pai de famílias e como tal deveria de dar exemplo a sua família e escravos (...). O Frei estava em consonância com o pensamento religioso da época. Vieira, Antonil e Benci acusavam os senhores de não combaterem a licenciosidade dos negros e os instavam a darem bons exemplos à comunidade.

Servimos-nos de algumas histórias individuais para iluminar este contexto e perceber as práticas costumeiras, e mais ainda, os conflitos advindos da pluralidade dos grupos sociais assentados nas distâncias $e$ desertos do sertão da Mantiqueira. As trajetórias que emergiram dessa preciosa documentação permitiram-nos questionar sobre o limite das escolhas realizadas por nossas personagens Inácia e Domingas. Optamos por entender estas escolhas como resultantes de uma série de condicionamentos que se não as determinavam, as constrangiam a aceitar a condição imposta por seus senhores. O que estamos propugnando aqui através destes casos, são as distintas experiências vividas pelos agentes sociais, fruto das relações dos distintos indivíduos com seu meio. Contudo, de acordo com nossa própria proposta metodológica, ressaltamos a impropriedade de generalizar e tipificar esses comportamentos. Próximas à Inácia e Domingas muitas outras mulheres criavam estratégias para sobreviverem no contexto adverso e permeado por valores misóginos. Muitas, certamente, como as próprias pesquisas indicam, utilizavam de sua autonomia para circularem no espaço das minas com liberdade, para formarem pecúlios, chefiavam domicílios e algumas ainda exerciam uma certa liderança carismática vinculada a estes ganhos ao estabelecer redes de parentesco rituais (FARIA, 2002; FURTADO, 1996). 


\section{Os autos das devassas e concubinato:}

O concubinato estava incluído no rol das culpas que deveriam ser averiguadas e condenadas pelas visitações. Diferentemente de L. Figueiredo, que o considera uma espécie de casamento alternativo diante dos obstáculos burocráticos e da pobreza da sociedade mineira, $\mathrm{R}$. Vainfas o vê como uma imposição do escravismo. Para ele, as altas taxas não se deviam tanto aos obstáculos burocráticos, mas seria resultante da falta de opções, de ofícios, da instabilidade e precariedade da vida das camadas mais empobrecidas (VAINFAS, 1989).

Renato Venâncio acompanha a longa trajetória de uma "cativa do Reino", enviada ao Novo Mundo por ser filha bastarda de seu proprietário, por variada documentação. Nesse percurso o autor teve acesso a preciosas informações que matizam o universo moral dos indivíduos envolvidos nos chamados "crimes de costumes" nomeados como concubinato. Muitas dessas relações na prática se referiam a uniões como "desponsais", ou "esponsais", como um "casamento por juras", não regulamentados pela igreja, mas utilizados como argumentos para comprovar que a união não era passageira, sem que fosse confundida com promiscuidade. Aliado a esta possibilidade Venâncio ainda salienta a importância do alto desequilíbrio sexual, tanto nas pequenas freguesias como nas áreas urbanas, que dispunha muitos homens livres para apenas poucas mulheres nessa mesma condição (VENÂNCIO, 2012, p. 43-74). Portanto, a grande incidência de relações de mancebia antes de ser vista como reflexo da precariedade da vida ou resultante dos obstáculos burocráticos deve ser vista como estratégia possível diante do quadro social que na perspectiva de Venâncio "deu origem a vários tipos de relações sexuais e familiares, que variavam da promiscuidade, passando por concubinatos mais ou menos estáveis até casamentos inter-raciais" (VENÂNCIO, 2012, p. 60) ${ }^{15}$.

Nessas primeiras décadas do XVIII, imperava uma enorme precariedade das condições de moradia, espaços de sociabilidade e serviços urbanos na Borda do Campo. Como fronteira aberta recentemente pela expansão, a que Cláudia Damasceno Fonseca denomina de expansão centrífuga no entorno das principais vilas, a localidade será ocupada por uma gente de cor que possivelmente

\footnotetext{
${ }^{15}$ Para comprovação desta perspectiva para a localidade em estudo seria necessário o levantamento da relação de gênero através dos assentos de óbito que, ao que tudo indica, deve ter tido uma presença muito superior de homens em relação ao de mulheres brancas ou livres, levando à formação de famílias concubinas. Mas até o momento não nos foi possível realizar tal empreitada.
} 
emigrou para lá (FONSECA, 2011). Não temos meios de discorrer sobre o índice de alforrias das propriedades locais, mas a exploração aurífera ainda estava em seu auge, o que certamente não favorecia as manumissões. Certamente a mobilidade espacial de que gozavam os libertos, as possibilidades de extração autônoma nas encostas e a presença de terras ainda devolutas, constituíssem fatores de atração para esse grupo se fixar naquelas áreas.

Durante o século XVIII a localidade recebeu cinco visitações, a cujas devassas tivemos acesso. À exceção de duas devassas por bebedeira, todas as demais, em um total de 150, foram abertas por prática de concubinato. Para uma visão geral das devassas abertas pelas visitações durante o século XVIII montamos o seguinte quadro:

Quadro 1 - Autos de Devassa por concubinato na Borda do Campo

Condição das mulheres envolvidas, 1730-1758

\begin{tabular}{|c|c|c|c|c|c|c|c|c|c|c|}
\hline \multirow{2}{*}{$\begin{array}{c}\text { Devassas } \\
\text { Total }\end{array}$} & \multicolumn{2}{|c|}{ Escravas } & \multicolumn{2}{|c|}{ Forras } & \multicolumn{2}{c|}{ Índias } & \multicolumn{2}{c|}{ Livres } & \multicolumn{2}{c|}{ S/inf. } \\
\cline { 2 - 11 } & No. & $\%$ & No. & $\%$ & No. & $\%$ & No. & $\%$ & No. & $\%$ \\
\hline 150 & 60 & 40 & 37 & 24,7 & 20 & 13,3 & 23 & 15,3 & 10 & 6,7 \\
\hline
\end{tabular}

Fonte: Devassas Eclesiásticas - Arquivo Eclesiástico da Cúria de Mariana/MG

A presença de altos índices de concubinato não era uma exclusividade dessa região e sim um traço recorrente nas vilas de toda Minas Gerais (PAIVA, 1989, p. 91-92). Especificamente sobre Vila Rica, Vidal Luna e Iraci Del Nero, ao pesquisarem as visitas diocesanas de 1738 chegaram a um percentual de $87,43 \%$ de casos de concubinato em 350 termos de culpa analisados (LUNA; COSTA, 1982, p. 5). Maria Leônia C. Resende ao analisar a frequência dos termos de culpa para toda a Comarca do Rio das Mortes levantou um número de 767 denúncias, sendo 660 delas por concubinato (RESENDE, 2003). As pesquisas, sem exceção, chegam a resultados semelhantes. Para R. Vainfas, forros, pobres, mestiços, pardos eram itinerantes, deserdados, inseguros, assim, por que haveriam de se casar? Para ele, o concubinato espelhava a instabilidade da vida (VAINFAS, 1989).

Consideramos igualmente que essa prática refletia as instabilidades na vida da colônia, mas não devemos generalizar e homogeneizar as condutas dos diferentes grupos ali estabelecidos. É importante levar em consideração fatores vinculados às escolhas 
individuais e de grupo e, principalmente, os fatores culturais que informam essas relações. A Capitania mineira, durante todo o século XVIII, caracterizou-se pelos altos índices de concubinato, devido à instabilidade, miséria, empecilhos burocráticos e principalmente, ao amálgama de diferentes valores culturais. Para os grupos cuja visão de mundo e práticas religiosas ainda não estivessem ressignificados por valores e práticas católicos, por que precisariam se submeter ao sacramento religioso para a satisfação de seus desejos? Certamente havia fronteiras entre esses grupos, eles possuíam diferentes papéis e não agiam homogeneamente (BARTH, 1981). Assim consideramos por nos remetermos ainda à primeira metade do século XVIII, mas, certamente com o passar do tempo, ocorrerá um processo de reconstrução de identidades destas diferentes etnias no ambiente colonial, a partir das novas experiências religiosas, vivência nas irmandades e realização das festas, "aonde agrupavam, cantavam, dançavam, recriavam afetos, buscavam proteção e cimentavam solidariedades" (BORGES, 2006). Como consequência, ocorrerá um lento processo de conversão ao catolicismo e daí uma maior aceitação de certos valores culturais próprios da tradição católica mesclados a elementos africanos e anímicos (BOSCHI, 1986, p. 60). No entanto, mesmo com essas diferentes orientações ali estabeleciam relações com alguns padrões comuns que os identificavam - viviam naquela comunidade, em condições de pobreza, subalternidade - e importavam-se pouco com o "pecado".

\section{“De portas adentro"}

$\mathrm{O}$ alto percentual de concubinatos encontrado nas fontes nos revela muito sobre a cotidianidade no interior das áreas rurais nos setecentos colonial mineiro. Através dessas uniões consensuais podemos ter acesso às tensões e aos conflitos que informavam as inter-relações entre os grupos ali estabelecidos. Vamos nos servir de algumas histórias individuais para compreender este contexto e melhor perceber as práticas costumeiras, no sertão da Mantiqueira.

(...) Luiz de Barros Souto Maior e seu filho Manoel de Barros, para satisfação da culpa que lhe resultou da devassa da visita do qual o dito Visitador admoestou em lapso de concubinato na forma do Sagrado Concílio Tridentino por consentirem duas negras e uma mulata e uma carijó suas escravas estejam vivendo de andar mal desse [?] nas suas portas para dentro inquietando sem pejo [?] nem 
temor de Deus as pessoas que vagamente passam por aquele distrito $(\ldots)^{16}$.

No conjunto de todas as devassas, esta nos chamou a atenção pela denúncia de atos ilícitos de não apenas uma concubina, como era comum, mas quatro e, dentre elas, uma índia, possivelmente administrada, mas que ali fazia parte do plantel de Luiz de Barros. Este alegou que "não eram consentidores de semelhantes culpas nem contentes de que suas escravas as cometessem, mas que por alguma omissão ou descuido de castigar e repreender como devem as ditas escravas". Justificou que eram pobres chefes de família e que ele possuía mais de sessenta anos e solicitou a comiseração do Visitador (FIGUEIREDO, 1993. p. 88-90 $)^{17}$. Este aceitou as justificativas e camaradamente condenou-os ao pagamento de uma pequena multa, absolvendo-os das demais penas e excomunhão. Ao que parece, a condição de pobreza e velhice do chefe da casa abonava a ilicitude dos atos e, como a absolvição fazia parte do ritual, independente da gravidade, os denunciados foram multados e a punição finalizada. A licenciosidade no uso da mão de obra escrava para fins de prostituição não foi questionada, afinal, como propriedade que era não caberia à igreja questionar este direito.

Optamos por identificar em cada uma das devassas a menção ao trato ilícito de senhores com suas escravas ou escravas de outrem e chegamos à percentagem de $40 \%$, conforme o quadro anterior. Esse fato, especialmente, escancara a face mais perversa da exploração escravista. Por mais que fontes de época demonstrem exceções a essa regra, discorrendo sobre relações de afeto e até duradouras de alguns senhores com suas cativas livrando-as do cativeiro por meio de testamentos, em sua grande totalidade as relações se baseavam no poder senhorial. Quando levados a julgamento, repetia-se a penalidade ritual: admitiase a culpa, o denunciado deveria lançar a escrava fora de sua casa e pagava-se uma multa irrisória. A Igreja procurava desta forma, intimidar a reprodução desta prática, em nome da família e preservação dos bons costumes. Atitude mais ineficaz, impossível. Senhores confundiam a exploração do trabalho com a sexual, acreditavam-se no direito de uso de sua propriedade, principalmente quando estas relações não afetavam

\footnotetext{
${ }^{16}$ Termo de delito e penalidade do denunciado - Borda do Campo - Arquivo Eclesiástico da Cúria de Mariana. MG - 20/09/1733.

${ }^{17} \mathrm{~L}$. Figueiredo fala sobre as casas de alcouce, quando proprietários de algumas vendas ou tabernas abriam espaço para o domicílio de mulheres forras e pobres, fazendo as vezes de alcoviteiros (FIGUEIREDO,1993. p. 88-90).
} 
as alianças familiares formais, o patrimônio da família e não expusessem publicamente a esposa (BRÜGGER, 1995). Mas não é difícil imaginar o impacto de uma acusação dessas, como a feita a Domingos Rodrigues, homem branco, casado, com sua escrava Domingas Francisca, crioula, solteira, ou ao Capitão Manoel Dias e sua cativa Maria, em uma localidade de diminutas proporções. Uma outra denúncia envolvendo o paulista Fernando Pinto Picapau, um homem branco, casado, em concubinato com a escrava Rosa exemplifica bem o caráter ordenador das visitações na região ${ }^{18}$. Foi exigido que ele "a lançasse fora e fosse fazer a vida com sua mulher". Ele, por sua vez considerava-se impedido de retornar, pois "corria risco de morte" em Guaratinguetá e que já enviara dinheiro para que sua mulher viesse. Sua trajetória nos revela muito dos paulistas que se embrenharam sertão a dentro e se misturaram à população local. John Monteiro aponta o efeito deste comportamento para a mestiçagem e surgimento de muitos domicílios chefiados por mulheres em São Paulo (MONTEIRO, 1994).

Simplício Tavares, homem livre e pobre, possuía uma longa trajetória com a mulata forra Águeda de Godói. Foram denunciados em 1730 pelo delito de concubinato. Feito o ritual de condenação, ele foi obrigado a colocá-la fora de casa e ambos pagaram uma multa. As informações ao final da página revelam que já haviam sido repreendidos antes, noutra freguesia, o que nos remete mais a uma relação estável do que fortuita ${ }^{19}$. Comprova esta consideração o fato de encontrarmos a mulata forra Águeda de Godói, na mesma localidade da Borda do Campo, em 1764, ou seja, 34 anos depois da última denúncia, vivendo em situação de miséria e de favor nas terras de um grande potentado local, junto à sua filha Benta Tavares ${ }^{20}$. A união com Simplício não the trouxe uma mudança de condição, o matrimônio oficial nem sequer foi formalizado, permaneceu por toda a sua vida sem superar sua condição de mulher forra e pobre, cuja união estável entrou para o rol dos concubinatos a serem reprimidos. Sua história nos leva a refletir sobre o segundo maior grupo de denúncias, ou seja, o envolvimento de homens livres com forras, mulatas forras e pardas forras.

\footnotetext{
${ }^{18}$ Termo de delito e penalidade do denunciado - Borda do Campo - Arquivo Eclesiástico da Cúria de Mariana. MG - 16/01/1730.

${ }^{19}$ Termo de delito e penalidade do denunciado - Borda do Campo - Arquivo Eclesiástico da Cúria de Mariana. MG - 16/01/1730.

${ }^{20}$ É quase um lance de sorte conseguir acompanhar traços de indivíduos tão empobrecidos como estes. Somente o esgotamento das fontes sobre determinada região abre essas possibilidades. Arquivo Público Mineiro - Casa dos Contos - Derrama - 1764.
} 
Tal como consideramos anteriormente, esse grupo pode estar mesclado com índias, muitas vezes consideradas também como pardas. Maria Leônia Chaves de Resende alerta que população indígena estava muito integrada à massa de mestiços e forros, dificultando sua real identificação. Muitos senhores administradores de índios escamoteavam a sua presença nos inventários o que acabava por abrir possibilidades de reescravização às gerações futuras (MONTEIRO, 1994). Por outro lado, os próprios índios escondiam-se atrás desta auto identificação para demarcar sua condição de livre (RESENDE, 2003).

Encontramos aqui um grupo de mulheres forras denunciadas caracterizadas pela condição de miséria em que viviam. Diferentemente daquelas que viviam nas grandes vilas e, por isso, tinham acesso à prestação de variados serviços e assim a um pecúlio, estas viviam em um povoado infiltrado nos sertões, ainda em sua terceira década de ocupação. Mulheres possuíam menores preços no mercado de escravos e os homens eram mais preferidos para o trabalho árduo nas lavras. Mulheres possuíam maior possibilidade de pecúlio pelo exercício de outras atividades acessórias como as amas de leite e até a prostituição, além de conseguirem obter maior grau de afetividade com seus senhores que lhe facultavam a alforria mais facilmente (FARIA, 2002). Ao mesmo tempo, usar da mobilidade em busca de melhores alternativas noutras áreas menos controladas se constituía a saída para muitas libertas. Muitas se dirigiam aos sertões e lá constituíam relações consensuais com homens livres, sempre ameaçadas pelo comportamento persecutório de toda comunidade. Juliana, mulata forra, foi admoestada em primeiro lapso de concubinato com Bernardo Gonçalves e este foi castigado e censurado "(...) e lhe mandou que no termo de vinte quatro horas a lance fora de casa (...)"21. O mesmo aconteceu com Gertrudes parda forra, denunciada por concubinato com Manoel Gomes da Silva, homem branco e solteiro, cuja pena foi lançá-la fora de casa no termo de dois dias ${ }^{22}$.

As forras circulavam nos distintos universos masculinos sempre condenadas pelo trato ilícito e poucas vezes recomendadas ao casamento, como acontecia a algumas mulheres brancas envolvidas em escândalos. O sacramento do matrimônio não deveria ser estendido a este grupo uma vez que simbolizava a ameaça de usurpação das fronteiras sociais.

${ }^{21}$ Termo de delito e penalidade do denunciado - Borda do Campo - Arquivo Eclesiástico da Cúria de Mariana. MG - 09/01/1730.

${ }^{22}$ Termo de delito e penalidade do denunciado - Borda do Campo - Arquivo Eclesiástico da Cúria de Mariana. MG - 07/05/1757. 
Na América Portuguesa o preconceito de sangue pesava sobre judeus e mouros, mas também sobre mulatos e negros. Os inquisidores, por exemplo, não se davam ao trabalho de investigar antecedentes de índios, mas a preocupação com o sangue negro era intensa. Africanos e seus descendentes seriam genuinamente impuros e infectados por carregarem o "peso horrível da mancha do vil nascimento" (STOLKER, 2006). Para concorrer a cargos burocráticos e ingressar em ordens militares e religiosas havia claros impedimentos à impureza de sangue.

No entanto, as relações fortuitas com as mulheres de cor eram praticadas mesmo por aqueles já privilegiados com as ordens militares, como mostra a devassa ocorrida envolvendo o tenente coronel José Lopes de Oliveira, tio do capitão Manoel Lopes de Oliveira, o maior proprietário de terras na região. José foi acusado por crime de concubinato com a forra Antonia da Luz em 1733. Anos depois, entre 1740 e 1759, ele aparece batizando doze filhos seus, fruto do casamento com Bernardina Caetana do Sacramento, filha de fidalgos portugueses ${ }^{23}$. Como a posição social era determinada pela origem genealógica o casamento endogâmico entre pessoas de mesmo status assegurava a descendência legítima da prole e perpetuava o poder das elites. Anos depois o denunciado José Lopes de Oliveira entrou com solicitação de mercê para tornar-se familiar do Santo Ofício, como homem honrado, cumpridor de seus deveres e sem mácula de sangue. Relações ilícitas, exploração e violência conjugavam-se com honra e mérito consagradas pelo Rei.

Não queremos, contudo, defender uma condição submissa das forras, reduzindo-as à exploração dos homens livres, incapazes de burlarem as regras e encontrarem brechas para se auto afirmarem. Pesquisas baseadas em testamentos e inventários destas mulheres descortinam variadas vivências, seja através do exercício de autonomia, acumulação de pecúlio, compra de escravos, até o controle sobre a repartição da herança sem, necessariamente, o beneficio dos parceiros (FARIA, 2002). O inventário da preta mina Vitória da Silva casada com Francisco Benguela, ambos forros nos faz entrever parte desta realidade. Vitória era contemporânea de Inácia, Domingas e de muitas outras que ainda não se beneficiavam de sua autonomia. Vitória ao final de sua vida deixou uma morada de casas e um escravo africano de herança a seus quatro filhos adultos e entre seus bens, oratórios, caixas e frasqueiras, além de estanho, ouro e joias e, como dívida passiva, três oitavas de

\footnotetext{
${ }^{23}$ Arquivo Eclesiástico da Cúria de Mariana. MG.
} 
ouro a um cirurgião dentista, ou seja, possuía bens, meios de distinção social, angariados certamente por uma outra experiência de liberdade ${ }^{24}$. Assim, várias experiências se conjugavam, às vezes no mesmo espaço e em se tratando de áreas mais ruralizadas, distantes das oportunidades e da dinâmica urbana, o espectro de oportunidades se restringiam restando a condição de subalternidade.

Voltando ao quadro 01, chegamos às devassas em cujo registro estava claramente mencionada a condição de índia, bastarda ou carijó. Incorporadas ao cenário colonial, algumas índias conseguiram sobreviver nas localidades, mas tendo sempre que enfrentar a discriminação e a sua redução ao cativeiro. Resende ressalta a dificuldade de recuperar as raízes étnicas desses grupos e a importância de se tentar recuperar suas raízes identitárias a partir de suas vivências. Vão estar mescladas à ampla população de cor da região das minas e buscarão meios de afirmar sua indianidade principalmente para assegurar a sua liberdade (RESENDE, 2003).

Na análise destas devassas sobressai a expressão como admoestação dos acusados "lhe mandou que em termos de dois dias a lance fora de casa" o que remete a percepção de que estas índias estavam em relações consensuais e duradouras, fora dos padrões aceitos pela igreja que tendia sempre a considera-las, além de ilícitas, fortuitas. Na denúncia feita ao Antonio Soares o Visitador foi impedido de aplicar a pena, pois a concubina Maria de Lira estava grávida e “(...) por isso não ser fácil separá-la sem perigo (...)". Como havia comprometido a se casar, os denunciados pagaram multa pelo escândalo ${ }^{25}$. Nestas situações, a mão do visitador era menos pesada e assumia um caráter mais ordenador da sociedade, do que necessariamente, punitivo.

Essa mesma postura se estende àquelas denúncias envolvendo pessoas livres, não necessariamente brancas, mas talvez de gerações mais distantes do cativeiro. Regrar comportamentos, corrigir más condutas e reafirmar o sacramento do casamento - estas eram as atitudes dos visitadores.

As viúvas eram também muito vitimadas pela censura, como a paulista Bárbara Ferreira culpada por primeiro lapso de concubinato com o português Manuel Machado Ribeiro. A este não foi imputada a pena para "lançá-la fora de casa" - exigida de todos os denunciados envolvidos com não-brancas - e sim foi mandado a ela "no temor de

\footnotetext{
$\overline{{ }^{24} \text { Inventário post mortem }}$ - Arquivo Altair Savassi - Barbacena.

${ }^{25}$ Termo de delito e penalidade do denunciado - Borda do Campo - Arquivo Eclesiástico da Cúria de Mariana. MG - 12/01/1730.
} 
dois dias para sair da casa do dito" 26 . Outras devassas como a feita a Custódio Joaquim da Costa, homem branco e casado, morador da Ibitipoca onde se encontrava às escuras com Maria da Conceição, viúva e moradora na mesma freguesia; a Manuel da Fonseca Lorato que foi mandado "fazer a vida com sua legítima mulher"; à Arcângela de Oliveira Cardoso que "tratasse de viver com seu marido como Deus manda" - este policiamento dos costumes buscava intimidar as práticas escandalosas que ameaçavam a ordem familiar na colônia. Observa-se a presença, mais diminuta de mulheres brancas pobres envolvidas nas denúncias. Estas sempre justificavam sua condição de pobreza para se safar das multas e receber somente penas penitenciais, como "rezando dez rosários de joelhos".

Esse caráter mais regulador e policialesco dos costumes esteve claro nas únicas duas devassas abertas por crime de bebedeira. O primeiro denunciado foi o Padre João Gomes da Costa, sacerdote do hábito de São Pedro e morador na freguesia. O citado bebia e se envolvia em confusões, causando escândalos e "grandíssimas ofensas a Deus Nosso Senhor". A pastoral católica no Novo Mundo esbarrava sempre na má formação dos sacerdotes e em seu baixo número para dar conta de tantas demandas.

\section{Outras vivências da gente de cor}

Baseamos-nos na concepção de que o perfil da sociedade instalada rapidamente nos sertões proibidos era marcado pela instabilidade dos grupos recém - chegados diante de uma tentativa intermitente de regulação por conta do Estado. Este Estado contou com a colaboração da instituição da Igreja em um primeiro momento, facilitado pela própria estrutura do padroado que impunha uma submissão do episcopado e dos clérigos aos desígnios metropolitanos. No entanto, por mais comprometidos que os visitadores estivessem com os interesses da Coroa, propugnava-se ali uma tarefa evangelizadora em consonância com a doutrina da Contra Reforma, expressa na pastoral disciplinadora e ordenadora das sociedades no Novo Mundo.

Mas acreditamos que outros nós da trama das relações sociais da comunidade da Mantiqueira precisam ser percebidos e não apenas através das lentes míopes dos visitadores. Através delas estamos

\footnotetext{
${ }^{26}$ Termo de delito e penalidade do denunciado - Borda do Campo - Arquivo Eclesiástico da Cúria
} de Mariana. MG - 24/07/1737. 
diante de uma sociedade anárquica e, por outro lado, sob a ótica dos governadores, seriam uma "gente intratável". Temos que buscar outras instâncias de vivências que recriavam identidades de grupo, superavam dificuldades e pudessem se traduzir em uma instância de sociabilidade, lazer e encontro desta gente. A existência de irmandades é um bom começo.

Paralelamente à construção de capelas em todo o processo de ocupação e formação de arraiais e vilas, confrarias se espalharam por todo o território mineiro, aproveitando as brechas da ausência de clérigos regulares. Elas se tornaram ambientes de devoção, onde caberia ao clero secular a realização dos sacramentos, mas também espaço para organização de cultos e festividades católicas conduzidas por leigos. Reuniam fiéis por suas devoções como também por suas diferentes categorias sociais se constituindo tanto em um espaço para os mais abastados quanto para os mais pobres. A existência de uma instância de reunião dos negros, escravos, libertos e seus descendentes, como aqueles que socialmente se apresentavam como pardos (talvez mais distantes do cativeiro) traduzia-se na possibilidade de criação de um projeto comum, no compartilhamento de experiências e fortalecimento dos laços em um contexto de pluralidades étnicas.

Os especialistas em religiosidade barroca em Minas Gerais no século XVIII são claros ao referenciar dezenas de irmandades de homens pardos e negros livres reunidos nas das Mercês e São Gonçalo e negros escravos e forros nas do Rosário, São Benedito e Santa Efigênia. Ressaltam o papel das festas, rituais, dramatizações e símbolos e seu papel no reordenamento cultural dos diversos grupos étnicos que compunham a sociedade mineira (BOSCHI, 1986; BORGES, 1998; DELFINO, 2015).

Temos informações acerca da formação de uma Irmandade da Boa Morte na Borda do Campo. Esta era uma confraria originalmente conduzida por mulheres libertas para pedir proteção na hora da morte a Nossa Senhora para que após a morte pudessem voltar à sua terra natal (BOSCHI, 1989). No arraial da Borda do Campo ela foi fundada em 1754 e oficialmente instituída em 1782. Os estatutos desta irmandade para outras vilas, a exemplo de São João Del Rei, declaravam que "se aceitavam pessoas brancas, pardos legítimos e libertos, assim como homens e mulheres que por sua devoção quisessem servir à mãe de Deus" (SANT'ANNA, 2006, p. 1205). Aos confrades era garantido socorro em caso de doença, viuvez ou desgraça, cortejos e enterros solenes. Era dever o pagamento de taxas de entrada, anuidades, acompanhar 
festejos, rezas, funerais e, em geral, eram condescendentes com aqueles de má situação financeira. No arraial da Borda do Campo esta confraria chegou a construir um templo. Anotações posteriores e esparsas sobre suas origens datam dos meados do século XIX, quando ela é descrita com uma boa arquitetura, tendo sido remodelada pelas muitas doações em testamento de figuras da própria elite local (MASSENA, 1985). Não tivemos acesso aos nomes dos filiados, mesmo porque seria muito difícil qualquer cruzamento dado a presença de homônimos, mas a detecção da existência de uma confraria como essa em um ambiente tão hostil como aquele apresentado até aqui demonstra quão dinâmicas eram as experiências e como pode ser enviesada uma perspectiva única. Há indicações nas fontes da presença de altares laterais com imagens como a de São Benedito, São Gonçalo do Amarante, São Luiz Gonzaga, São Manuel Mártir e outros. Esta informação sinaliza que outras devoções próprias de negros, libertos e descendentes foram veneradas em altares laterais da igreja ${ }^{27}$.

Há referências sobre a presença de outras irmandades de pretos e libertos na região, a exemplo da Irmandade do Rosário, fundada pelos negros por volta de 1774, mas com seu compromisso aprovado somente em 1810, quando Piedade da Borda do Campo já teria se tornado a Vila de Barbacena. Há registros de outras Igrejas do Rosário em Nossa Senhora do Ibitipoca e São Domingos da Bocaina também nas primeiras décadas do XIX. Leonara Delfino a partir dos dados dos entrantes do Rosário em Barbacena, entre 1812 e 1850, revelou a participação de escravos africanos e crioulos, além de forros, pardos e outros livres, um comportamento comum dos Rosários, ao autorizar a entrada de mestiços e brancos (DELFINO, 2015).

Charles Boxer acentua que as irmandades eram um singular elemento do processo de colonização vigente sob o Antigo Regime, por onde os grupos subalternos manifestavam sua relativa autonomia (BOXER, 2014, p. 326). Para Caio Boschi eram local para afirmação de identidades culturais e étnicas ou sociais dos integrantes (BOSCHI, 2014, p. 326). Portanto, pertencer a irmandades como esta poderia configurar uma estratégia em função da posição assumida e dos parcos recursos a que esse grupo tinha acesso naquela sociedade instalada nos sertões. Essa prática, por sua vez, repercutia no estabelecimento

\footnotetext{
${ }^{27}$ Leonara Lacerda considera difícil confirmar se houve formação de juizados organizados para esses santos, com eleições, mesas diretivas e festejos aos santos patronos. Ela acredita que para São Benedito houve festas e reinados, em função do registro de uma coroa ao santo (DELFINO, 2015).
} 
de solidariedades horizontais, na maior socialização e recriação de identidades. Portanto, a "gente intratável", na visão de cima, usava das brechas que possuía para subverter a sua dura realidade.

\section{Referências}

ARIÈS, Philippe. Por uma história da vida privada. In: CHARTIER, Roger (Org.). História da Vida privada 3. Da Renascença ao Século das Luzes. São Paulo: Cia das Letras, 2009.

BARTH, Fredrik. Process and form in social life. v. 1. Londres: Routlegde \& Kegan Paul, 1981.

BERTRAND, Michel. Los modos relacionales de las elites hispanoamericanas coloniales: enfoques e posturas. Anuário del IEHS, Tandil, n. 15, 2000.

BORGES, Célia Maia. A festa do Rosário: a alegoria barroca e a reconstrução das diferenças. Disponível em: <http://www.upo.es/depa/webdhuma/areas/arte/4cb/pdf/ C\%C3\%A9lia\%20Maia\%20Borges.pdf>. Acesso em: 17 fev. 2015.

. Os leigos e o poder. Irmandades leigas e política colonizadora em Minas Gerais. São Paulo: Ática, 1986.

BOXER, Charles R. O império marítimo português 1415-1825. Lisboa: Edições 70, 1977.

BRÜGGER, Sílvia Maria Jardim. Valores e vivências matrimoniais: o triunfo do discurso amoroso (Bispado do Rio de Janeiro, 1750-1888). Dissertação (Mestrado em História) - Universidade Federal Fluminense (UFF), Niterói, 1995.

CAPRI, Roberto. Minas Gerais e seus municipios. São Paulo: Capri, Andrade \& C. Editores, 1916.

CRUZ, Elias F. S. As visitas diocesanas nas Minas setencentistas. Poder Episcopal e Sociabilidades na Comarca do Rio das Mortes na primeira metade do século XVIII. Dissertação (Mestrado em História) - Universidade Federal de Juiz de Fora (UFJF), Juiz de Fora, 2009

DELFINO, Leonara Lacerda. O Rosário dos irmãos escravos e libertos: fronteiras, identidades e representações do viver e morrer na diáspora atlântica. Freguesia do Pilar - São João Del Rei (1872-1850). Tese de doutorado (História) - Universidade Federal de Juiz de Fora (UFJF), Juiz de Fora, 2015.

FARIA, Sheila de C. Mulheres Forras - riqueza e estigma social. Tempo - História das Mulheres e Relações de Gênero, Niterói, v. 5, n. 9, p. 65-92, jul. 2002.

FIGUEIREDO, Luciano de A. R. Barrocas Famílias: vida familiar em Minas Gerais do século XVIII. São Paulo: Hucitec, 1997.

. O avesso da memória: cotidiano de trabalho da mulher em Minas Gerais no século XVIII. Rio de Janeiro: José Olympio, 1993.

FIGUEIREDO, Luciano de A. R.; SOUSA, Ricardo Martins. Segredos de Mariana: Pesquisando a Inquisição Mineira. Acervo - Revista do Arquivo Nacional, Rio de Janeiro: Arquivo Nacional, v. 2, n. 2, p. 11-37, jul./dez., 1987.

FURTADO, Junia Ferreira. O livro da Capa verde. São Paulo: Anablume, 1996. 
FONSECA, Cláudia D. Arraiais e vilas D'El Rei, Espaço e Poder nas Minas Setecentistas. Belo Horizonte: Ed. UFMG, 2011.

FRAGOSO, João Luís Ribeiro. A nobreza da República: notas sobre a formação da primeira elite senhorial do Rio de Janeiro (séculos XVI e XVII). Topoi, Rio de Janeiro, v. 1, p. 123-152, 2000.

FREIRE, Gilberto. Casa Grande e Senzala. Formação da família brasileira sob o regime da economia patriarcal. 20. ed. Rio de Janeiro: 1989. Disponível em: <http:// historia_demografica.tripod.com/pesquisadores/paco/pdf-paco/ar21.pdf>. Acesso em: 21 fev. $\overline{2} 015$.

KÜHN, Fábio. As redes da distinção: familiares da Inquisição na América Portuguesa do século XVIII. Varia História, Belo Horizonte, v. 26, n. 43, p. 177-195, jan./jun. 2010.

LEVI, G. Reciprocidade mediterrânica. In: OLIVEIRA, Mônica Ribeiro de; ALMEIDA, Carla Maria Carvalho. Exercícios de Micro História. Rio de Janeiro: EDFGV, 2009.

LUNA, Francisco Vidal; COSTA, Iraci del Nero da. Devassa nas Minas Gerais: Observações sobre casos de concubinato. Anais do Museu Paulista, São Paulo, v. 31, p. 221-233, 1982.

MASSENA, Nestor. Barbacena: a terra e o homem. Belo Horizonte: Imprensa Oficial, 1985.

MONTEIRO, John. Negros da Terra. Índios e Bandeirantes nas Origens de São Paulo. São Paulo: Companhia das Letras, 1994.

PAIVA, Eduardo França. Escravidão e universo cultural na colônia: Minas Gerais, 1716-1789. Belo Horizonte: Editora UFMG, 2001.

PAIVA, José Pedro de Matos. Inquisição e visitas pastorais: Dois mecanismos complementares de controle social? Revista História das Ideias, Coimbra, v. 11, p. 85-102, 1989.

RESENDE, Maria Leônia Chaves de. Gentios Brasílicos. Índios coloniais em Minas setecentista. Tese de Doutorado (História) - Universidade de Campinas (UNICAMP), Campinas, 2003.

SANT'ANNA, Sabrina Mara. As Irmandades mineiras de Nossa Senhora da Boa Morte: assistencialismo, devoção e festejos. Disponível em: <http://www.upo.es/depa/ webdhuma/areas/arte/4cb/pdf/Sabrina\%20Mara.pdf>. Acesso em: 02 mar. 2015.

SOUZA, L.M. O diabo e a Terra de Santa Cruz. Feitiçaria e religiosidade popular no Brasil colonial. São Paulo: Companhia das Letras, 1986.

STOLKER, Verena. O enigma das interseções: classe, "raça", sexualidade. A formação dos impérios transatlânticos nos séculos XVI ao XIX. Revista estudos feministas, Florianópolis, v. 14, n. 1, p. 15-42, jan./abr., 2006.

TORRES-LONDOÑO, Fernando. A outra família. Concubinato, igreja e escândalo na colônia. São Paulo: Loyola, 1999.

VAINFAS, Ronaldo. Trópico dos pecados: moral, sexualidade e inquisição no Brasil. Rio de Janeiro: Editora Campus, 1989.

VENÂNCIO, Renato P. Cativos do Reino. A circulação de escravos entre Portugal e Brasil, séculos XVIII e XIX. São Paulo: Alameda, 2012. 